\title{
Characterization and Evaluation of Agricultural Benchmark Soils from Sevilla, Spain ${ }^{1}$
}

\author{
D. DE la Rosa, J. L. MudarRa, R. RoMero, AND J. MARTín-ARanda ${ }^{2}$
}

\section{ABSTRACT}

In Sevilla Province, southwestern Spain, benchmark soils of eight agricultural areas were defined using traditional soil pedon concepts of soil survey. The characterization emphasized morphological, chemical, and physical analyses. These eight representative soils were classified as follows: Rojo Aljarafe (Typic Rhodoxeralf), Tierranegra Campo (Typic Pelloxerert), Salino Marismas (Vertic Fluvaquent), Franco Vega (Typic Xerofluvent), Arena Terrazas (Aquic Haploxeralf), Almagra Alcores (Calcic Haploxeralf), Bujeo Campiña (Typic Chromoxerert), and Albariza Estepa (Entic Haploxeroll). By application of a computer-based soil evaluation system developed with information from a representative zone, predicted yields were calculated for wheat (Triticum aestivam L), field corn (Zea mays $L_{*}$ ), and cotton (Gossypium hirsutum $L_{*}$ ) for the selected benchmark soils. Productivity information was transferred from the representative zone to the eight agricultural areas within Sevilla Province. Soils were ranked in the following order according to predicted yields for the three crops: Bujeo Campiña > Tierranegra Campo > Franco Vega $>$ Salino Marismas $>$ Rojo Aljarafe $>$ Almagra AIcores $>$ Albariza Estepa $>$ Arena Terrazas.

Additional Index Words: soil classification, soil survey, statistical model application, soil suitability.

De la Rosa, D., J.L. Mudarra, R. Romero, and J. Martin-Aranda. 1984. Characterization and evaluation of agricultural benchmark soils from Sevilla, Spain. Soil Sci. Soc. Am. J. 48:358-362.

$I^{2}$ N Sevilla Province, approximately 900000 ha of the total area of 1.4 million ha are considered agricultural soils. Previous investigations $(7,15) \mathrm{em}-$ phasized soil genesis and spatial distribution of soil. There remains a great need for basic data and interpretations of representative soils in this province.

Benchmark soils are those that, because of their large extent, key position in the classification systems, or ocurrence in critical areas, are important to the understanding of soils (13). These authors also reported that it is impossible to make detailed studies of all soils because of their vast numbers. The practical approach is to obtain a thorough understanding of soil behavior thorough detailed investigations on a few important soils. Information about these benchmark soils can then be extended to those soils that are closely related in classification and geography.

Soil data need to be translated from the complex scientific language of the soil scientist to simple expressions of soil behavior that soil information users can understand. According to Bartelli (2), this constitutes soil survey interpretation. Soil evaluations, synonymous with soil survey interpretations, are predictions of performance, not recommendations for the use of soils (3). Productive capacity or expected yields are useful in predicting the suitability of any soil for

\footnotetext{
${ }^{1}$ Contribution from the Centro de Edafologia y Biologia Aplicada del Cuarto, C.S.I.C., P.O. Box 1052, Sevilla, Spain. Received 24 Feb. 1982. Approved 3 Nov. 1983.

${ }^{2}$ Soil Scientists, Soil Chemist, and present Director, respectively. The Senior Author is now Head, Sección de Conservación de Suelos, Dirección General de Medio Ambiente, Junta de Andalucía, Sevilla, Spain.
}

agricultural use. There is a tendency to make the analysis of productivity more complete by identifying and quantifying all ecological components (17) where climate is, of course, the principal variable. However, in ecological units where natural and socio-economic factors are considered constant, evaluations of soilproductive capacity based on soil properties can supply a satisfactory estimate of variation in crop yields. At the present time, a methodology which uses computer-based models provides increased precision for estimates of expected yields from soils (9). Although the models are calibrated with soil and crop yield data relating to a representative zone, these models can be useful to transfer agronomic information to other similar areas (4).

Benchmark soils of eight agricultural areas from Sevilla Province were characterized in this study. By application of a computerized soil evaluation system (1 1) developed with information from a representative zone, yields of wheat (Triticum aestivum L.), corn (Zea mays L.), and cotton (Gossypium hirsutum L.) for the selected benchmark soils were predicted. It is intended that this paper will lead towards a Regional Soil Catalogue, which will identify, define, describe and give the agricultural and nonagricultural qualities of benchmark soils.

\section{MATERIALS AND METHODS}

The study areas are located in the Province of Sevilla, Andalucia Region, Spain. The approximate geographic coordinates are $5^{\circ} 00^{\prime}$ to $6^{\circ} 30^{\prime} \mathrm{W}$ and $37^{\circ} 00^{\prime}$ to $38^{\circ} 00^{\prime} \mathrm{N}$. Elevation of the areas range from 2 to $500 \mathrm{~m}$ above sea level. The climate is Mediterranean, with moist and cool winters, and warm and dry summers. The average annual temperature approaches $18^{\circ} \mathrm{C}$ and annual rainfall is about $600 \mathrm{~mm}$.

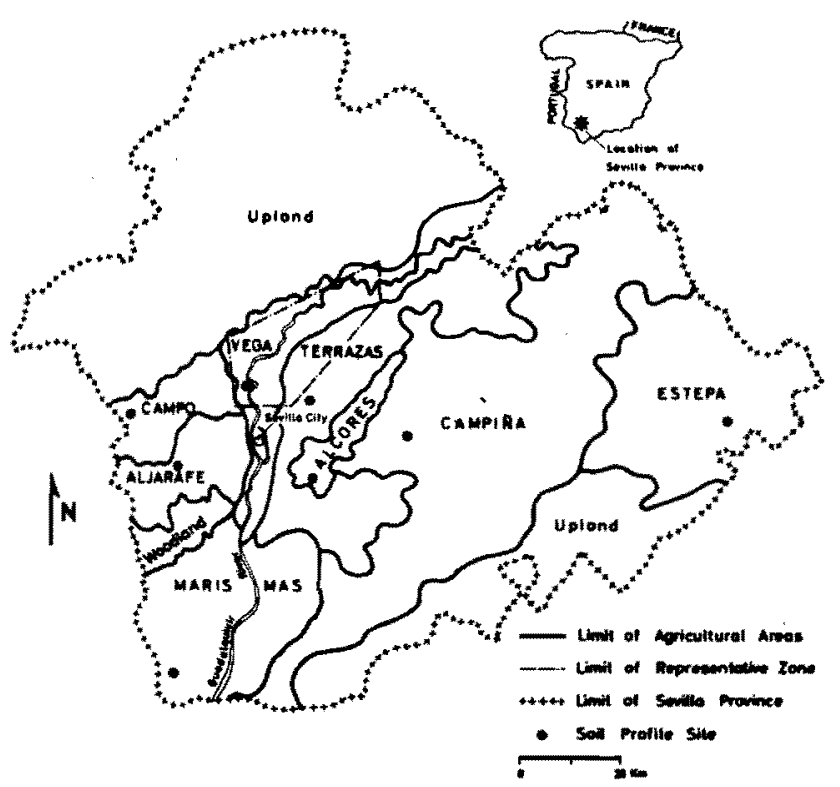

Fig. 1-Location of study soils, agricultural areas, and the representative zone within the Province of Sevilla. 
A general description of each area is summarized in Table 1.

On the basis of the completed soil survey of the Sevilla Province $(7,10,15)$, the discussed soils were selected because they occupy large proportions of the study areas. However, inclusions of soils significantly different in each area can be recognized. Location of the selected benchmark soils and the agricultural study areas are given in Fig. 1.

Pits necessary to examine each soil were dug to a depth of $2 \mathrm{~m}$. Profiles were described and sampled. Morphological descriptions were recorded following the nomenclature specified in the Soil Survey Manual (18). Soils were classified according to the method outlined by the Soil Survey Staff (20).

Soil $\mathrm{pH}$ was measured in water and in $1 \mathrm{~N} \mathrm{KCl}$ using a 1:1 soil-to liquid ratio. Organic $C$ was determined by the Walkley-Black procedure (1). Nitrogen was analyzed by Kjeldahl digestion (19). Salinity was determined by the electrical conductivity (EC) of saturation extract (19). Carbonate content was measured by a volumetric nethod (19). Cation exchange capacity (CEC) was determined by the $\mathrm{NH}_{4} \mathrm{OAc}$ method at $\mathrm{pH} 7$ (19). Exchangeable $\mathrm{Na}$ was extracted in $1 \mathrm{~N}$ $\mathrm{NH}_{4} \mathrm{OAc}(8)$. Sodium saturation (exchangeable $\mathrm{Na}$ percentage, ESP) was calculated by dividing exchangeable $\mathrm{Na}$ by CEC. Standard procedures were used in determining bulk density by the core method, hydraulic conductivity in water saturated samples, and water retention at 1/3 and 15 bar tension (19). Particle-size distribution (fractions $2-0.2 \mathrm{~mm}$, $0.2-0.02 \mathrm{~mm}, 0.02-0.002 \mathrm{~mm},<0.002 \mathrm{~mm}$ ) were determined by the hydrometer method (5).

Agricultural evaluation of the selected benchmark soils was determined by application of the system developed by De la Rosa et al. (11). This system was developed in a representative zone of Sevilla Province (Fig. 1) for predicting yields of wheat, field corn, and cotton on the basis of selected soil properties when cropped under a high level of management. The procedure consisted of computing polynomial models following analyses by multiple regression (11).

\section{RESULTS AND DISCUSSION}

\section{Soil Characterization}

Profile descriptions and analytical characterization of selected benchmark soils are summarized in Tables 2 and 3. The Rojo Aljarafe profile presents strong textural profile differentiation with a red solum ( $A$ and $B$ horizons). With increasing depth, organic matter decreases and carbonate content increases. Cation exchange capacity follows a trend similar to clay content. Although not shown, base saturation is nearly $100 \%$ in the entire profile. This soil has a moderate permeability and available water capacity. In this Mediterranean region, most of these soils ( $R$ hodoxeralfs) have formed under climatic conditions considerably different from the present conditions (6).

The Tierranegra Campo profile is a very dark clayey soil. The dominant mineral of the clay fraction $(<2$ $\mu \mathrm{m})$ is montmorillonite (7), which contributes to a high shrink-swell potential and CEC $\left(>0.35 \mathrm{~mol} \mathrm{~kg}^{-1}\right)$. During dry seasons, deep cracks of considerable width develop in these soils. The carbonate content is high through the entire profile. The hydraulic conductivity is very low except in the cracks, and the available water capacity is high ( $>16 \%$ by weight).

The Salino Marismas profile has a gray color and clay texture in the Alsa horizon. The clay fraction is predominantly illite in a advanced degree of alteration (14). The most important characteristic of this soil is
Table 1-General descriptions of the agricultural areas considered in the study.

Area Description

Aljarafe An area of calcareous, fine-grained sandstone (Mio-Pliocene). The general relief varies from moderately undulating to level (slopes of 1-8\%). Well-drained and moderately well-drained soils predominate this area. This area supports mainly olive, citrus, grapevine, and annual crops. Its approximate area is 43000 ha.

Campo A region of depressed surfaces of Mio-Pliocene parent material mostly calcareous, high in clay, and nearly impervious. Range in slope is 1 to $8 \%$. The soil-drainage class is imperfectly or somewhat poorly drained. Present land-use pattern includes the following principal crops: wheat, corn, cotton, sunflower, and sugar beet. The approximate area is 25500 ha.

Marismas Deposits of shale (Holocene) with appreciable amounts of salts located on the lower Guadalquivir Valley. The relief is level with slopes $<3 \%$. The soils are very poorly drained. Presently the salinity of a large part of the total a rea has been considerably reduced by land reclamation, and the soils are dedicated to anmual crops. The approximate area is $103500 \mathrm{ha}$.

Vega A region of stabilized well-drained alluvial fans (Holocene), with inclusions of other phy siographic Pleistocene landforms. The relief is nestly level (slopes $<3 \%$ ). This a rea supports mainly citrus, cotton, corn, wheat, and potatoes. Its approximate area is 74000 ha.

Terrazas Weakly dissected fluvial terraces (Pleistocenel overlying Mio cenic geological materials. The Guadalquivir River has four major terrace levels in this area, with a nearly level general relief (slopes $<3 \%$ ). The solls range from well drained to poorly drained. Present land-use pattern includes the following crops: olive, wheat, corn, sunflower, and cotton. The approximate area is 133000 ha.

Alcores A region which containg deposits of highly calcareous sand: stone (Pliocene) with isolated very old terrace landforms. The relief varies from gently undulating to level (slopes of $1-8 \%$ ). The soils are well drained and moderately well drained. This area supports mainly olive, citrus, wheat and sunflower. Its approximate area is 18000 ha.

Campiña The area contains formations of caicareous and high clay materials (Oligo-Miocene), with inclusions of terraces of various levels. The general relief is moderately undulating (slopes of $1-8 \%)$. Somewhat poorly drained soils predominate in this area. Present land-use pattern includes annual crops, such as wheat, corn, cotton, and sunflower. The approximate area is 330500 ha.

Estepa A region which contains a formation of highly calcareous ma* terials (Eo-Miocenel. The relief ranges from undulating to slightly undulating (slopes of $1-16 \%$. Well drained soils dominate the area. Olive is the most common crop, although the area also supports wheat, sunflower and corn. The approximate area is $140000 \mathrm{ha}$.

its very high salt content $\left(\mathrm{EC}>45 \mathrm{dS} \mathrm{m}^{-1}\right)$. The $\mathrm{pH}$ $(<8.0)$ corresponds to values for saline, nonsodic soils. However, the level of exchangeable Na (ESP $>20 \%$ ) is very high. The adverse physical properties, especially hydraulic conductivity, are further compounded by this high level of exchangeable $\mathrm{Na}$ along with the high clay content.

The Franco Vega profile shows only weak evidence of soil formation (e.g., high carbonate content and weak structure development). It has a pale brown, sandy clay loam Ap horizon moderately rich in organic matter and natural fertility. Hydraulic conductivity is moderate $\left(\sim 1 \mathrm{~cm} \mathrm{~h}^{-1}\right)$ through all the profile and available water capacity is moderately high.

The Arena Terrazas profile is yellowish brown and very sandy in the Ap and $B I$ horizons. With increasing depth, clay content and CEC increase and organic matter decreases. Only the deepest horizion $(\mathrm{B} 3 \mathrm{~g})$ contains free carbonates. Bulk density is very high, and 
infiltration of water is slow, especially in the argillic horizon (B2 and $\mathrm{B} 3$ ). It is interesting to note the hydromorphic characteristics of these soils with free Mn and $\mathrm{Fe}$ contents tending to be higher in the $\mathrm{B}$ horizon (16). It could be hypothesized that the absence of carbonates permits the formation of argillans to take place within the argillic horizon in response to the infrequent percolation of water.

The Almagra Alcores profile is highly weathered, and presents characteristics very similar to those of the Rojo Aljarafe soil. It also has calcareous parent materials and a red solum, sandy clay loam texture in the Ap horizon, and a maximum clay content in the $B 2 t$. The CEC is low, which suggests that the clay fraction is predominantly formed by illite and kaolinite (12). Through the profile, the physical properties follow a trend similar to that of the Rojo Aljarafe pedon.

The Bujeo Campiña profile presents strong vertic characteristics. Its solum has a dark grayish-brown color, and clay texture. Electrical conductivity levels are less than $4 \mathrm{dS} \mathrm{m}^{-1}$ in the $\mathrm{A}$ and $\mathrm{Cl}$ horizons, indicating low soluble salts. These values increase with depth and correspond to higher ESP levels. The carbonate content is very high $(>30 \%)$ through the entire profile. Physical properties are very similar to those of the Tierranegra Campo profile.

The Albariza Estepa profile is a slightly weathered soil formed on very calcareous materials, with a moderately dark grayish surface layer (A horizon). The soil is high in clay $(>35 \%$ ), with a high $\mathrm{pH}$. Organic $\mathrm{C}$ contents decrease strongly with depth. The old terms Rendzina and Xerorendzina were primarily used for defining these soils (7).

\section{Agricultural Potential Evaluation}

Predicted yields for wheat, corn, and cotton crops, effective depth, depth to hydromorphic features, and the control section for each benchmark soil are given in Table 4. The applied soil evaluation system (11) assumes that field variability of crop yield is a consequence of the variability in plant genetic properties in addition to environmental factors. Spatial variability between soils in yield of a given crop grown, under the same climate and management level, is determined mainly by soil variability. The models given by De la Rosa et al. (11) were constructed to be used as submodels of possible soil-plant atmospheric models for predicting crop yields of land unit. These assumptions need to be kept in mind to discuss properly the results of soil evaluation process (Table 4), and to consider these results as preliminary.

The soil represented by Franco Vega profile (Table 4) produces the maximum predicted yield for wheat. Franco Vega soil has nearly ideal physical and chemical properties for plant growth (10). The Arena Terrazas soil produces the minimum predicted yield, not only for wheat but also for corn and cotton. This soil has unfavorable physical and chemical properties, mainly useful depth and depth to hydromorphic features, that limit root growth. The B2 horizon has a high clay content with very low hydraulic conductivity. The Bujeo Campiña and Albariza Estepa soils produce the most similar predicted yields of wheat. One
Table 2-Morphologic properties of the selected soil profiles. $\dagger$

\begin{tabular}{|c|c|c|c|c|c|c|}
\hline $\begin{array}{l}\text { Hori- } \\
\text { zon }\end{array}$ & $\begin{array}{c}\text { Depth, } \\
\mathrm{cm}\end{array}$ & $\begin{array}{l}\text { Munsell } \\
\text { color } \\
\text { (dry) }\end{array}$ & $\begin{array}{l}\text { Tex- } \\
\text { ture }\end{array}$ & $\begin{array}{c}\text { Struc- } \\
\text { ture. }\end{array}$ & $\begin{array}{c}\text { Con- } \\
\text { sistence } \\
\text { (moist) }\end{array}$ & $\begin{array}{c}\text { Bound- } \\
\text { ary }\end{array}$ \\
\hline \multicolumn{7}{|c|}{ Rojo Aljarafe (Typic Rhodoxeralfs) } \\
\hline $\begin{array}{l}\text { Ap } \\
\text { B1 } \\
\text { B2t } \\
\text { B3 } \\
\text { Cca }\end{array}$ & $\begin{array}{c}0-30 \\
30-55 \\
55-110 \\
110-120 \\
120-150\end{array}$ & $\begin{array}{r}5 \text { YR } 7 / 8 \\
5 \text { YR } 4 / 6 \\
2.5 \text { YR } 4 / 8 \\
7.5 \text { YR } 6 / 8 \\
5 \text { YR } 8 / 2\end{array}$ & $\begin{array}{l}\text { sel } \\
\text { sel } \\
\text { se } \\
\text { sl } \\
\text { sl }\end{array}$ & $\begin{array}{l}\text { f3sbk } \\
\text { m3sbk } \\
\text { m3pr } \\
\text { f3pr } \\
0\end{array}$ & $\begin{array}{l}\mathrm{mfr} \\
\mathrm{mfi} \\
\mathrm{mvfi} \\
\mathrm{mfi} \\
\mathrm{mfr}\end{array}$ & $\begin{array}{l}\mathrm{cs} \\
\mathrm{cw} \\
\mathrm{cw} \\
\mathrm{gw}\end{array}$ \\
\hline \multicolumn{7}{|c|}{ Tierranegra Campo (Typic Pelloxererts) } \\
\hline $\begin{array}{l}\text { Ap } \\
\text { A1 } \\
\text { AC } \\
\text { C }\end{array}$ & $\begin{array}{c}0-20 \\
20-60 \\
60-140 \\
140-170\end{array}$ & $\begin{array}{l}10 \mathrm{YR} 4 / 1 \\
10 \mathrm{YR} 3 / 1 \\
10 \mathrm{YR} 3 / 1 \\
10 \mathrm{YR} 8 / 4\end{array}$ & $\begin{array}{l}c \\
c \\
c \\
c\end{array}$ & $\begin{array}{l}\text { m3gr } \\
\text { m3abk } \\
\text { c3pr } \\
\text { m }\end{array}$ & $\begin{array}{l}\text { mfi } \\
\text { mvfi } \\
\text { mvfi } \\
\text { mvfi }\end{array}$ & $\begin{array}{l}\text { gw } \\
d \\
\text { gw }\end{array}$ \\
\hline \multicolumn{7}{|c|}{ Salino Marismas (Vertic Fluvaquents) } \\
\hline $\begin{array}{l}\text { A1sa } \\
\text { C1sa } \\
\text { C2sa } \\
\text { IIC3sa }\end{array}$ & $\begin{array}{c}0-10 \\
10-20 \\
20-100 \\
100-150\end{array}$ & $\begin{array}{r}10 \mathrm{YR} 7 / 1 \\
10 \mathrm{YR} 4 / 2 \\
7.5 \mathrm{YR} 5 / 4 \\
5 \mathrm{YR} 4 / 1\end{array}$ & $\begin{array}{l}\mathbf{c} \\
\mathbf{c} \\
\mathbf{c} \\
\mathbf{c}\end{array}$ & $\begin{array}{l}\text { c3abk } \\
\text { c3sbk } \\
\text { m } \\
m\end{array}$ & $\begin{array}{l}\text { mvfi } \\
\text { muti } \\
\text { mefi } \\
\text { mefi }\end{array}$ & $\begin{array}{l}\mathrm{cs} \\
\mathrm{cs} \\
\mathrm{cs} \\
-\end{array}$ \\
\hline \multicolumn{7}{|c|}{ Franco Vega (Typic Xerofluvents) } \\
\hline $\begin{array}{l}\text { Ap } \\
\text { C1 } \\
\text { C2 } \\
\text { C3 }\end{array}$ & $\begin{array}{c}0-25 \\
25-55 \\
55-80 \\
80-150\end{array}$ & $\begin{array}{l}10 \text { YR } 6 / 3 \\
10 \mathrm{YR} 6 / 3 \\
10 \mathrm{YR} 4 / 4 \\
10 \mathrm{YR} 5 / 4\end{array}$ & $\begin{array}{l}\mathrm{scl} \\
\mathrm{scl} \\
\mathrm{sel} \\
\mathrm{sel}\end{array}$ & $\begin{array}{l}\text { mlsbk } \\
\text { ml sbk } \\
0 \\
0\end{array}$ & $\begin{array}{l}\text { mfr } \\
\text { mfr } \\
\text { mvfr } \\
\text { mvfr }\end{array}$ & $\begin{array}{l}\mathrm{cs} \\
\mathrm{cs} \\
\mathrm{gs}\end{array}$ \\
\hline \multicolumn{7}{|c|}{ Arens Terrazas (Aquic Haploxeralfs) } \\
\hline $\begin{array}{l}\text { Ap } \\
\text { B1 } \\
\text { B21tg } \\
\text { B22tg } \\
\text { B3tg }\end{array}$ & $\begin{array}{c}0-25 \\
25-40 \\
40-70 \\
70-110 \\
110-150\end{array}$ & $\begin{array}{l}10 \text { YR } 5 / 4 \\
10 \text { YR } 7 / 6 \\
10 \text { YR } 5 / 6 \\
10 \text { YR } 5 / 6 \\
10 \text { YR } 5 / 6\end{array}$ & $\begin{array}{l}\text { ls } \\
\text { sl } \\
\text { sc } \\
\mathrm{sc} \\
\mathrm{sc}\end{array}$ & $\begin{array}{l}\text { fler } \\
\text { c3sbl } \\
\text { c3pr } \\
\text { c3pr } \\
\text { c2pr }\end{array}$ & $\begin{array}{l}\mathrm{mfi} \\
\mathrm{mfr} \\
\mathrm{mfr} \\
\mathrm{mfr} \\
\mathrm{mfr}\end{array}$ & $\begin{array}{l}\mathrm{cs} \\
\mathrm{gw} \\
\mathrm{d} \\
\mathrm{gw} \\
-\end{array}$ \\
\hline \multicolumn{7}{|c|}{ Almagra Alcores (Calcic Haploxeralfs) } \\
\hline $\begin{array}{l}\text { Ap } \\
\text { AB } \\
\text { B2t } \\
\text { B3ca } \\
\text { C1ca } \\
\text { IIC2ca }\end{array}$ & $\begin{array}{c}0-20 \\
20-45 \\
45-60 \\
60-75 \\
75-115 \\
115-200\end{array}$ & $\begin{array}{r}5 \text { YR } 4 / 8 \\
2.5 \text { YR } 5 / 6 \\
2.5 \text { YR } 5 / 6 \\
5 \text { YR } 5 / 6 \\
5 \text { YR } 6 / 8 \\
10 \text { YR } 6 / 6\end{array}$ & $\begin{array}{l}\text { scl } \\
\text { sc } \\
\text { sc } \\
\text { sl } \\
1 \\
\text { is }\end{array}$ & $\begin{array}{l}\text { facr } \\
\text { cler } \\
\text { c3abk } \\
\text { f3abk } \\
\text { f2abk } \\
\text { c3bk }\end{array}$ & $\begin{array}{l}\mathrm{mfr} \\
\mathrm{mfr} \\
\mathrm{mfi} \\
\mathrm{mfi} \\
\mathrm{mfi} \\
\mathrm{mfi}\end{array}$ & $\begin{array}{l}\mathrm{gs} \\
\mathrm{cs} \\
\mathrm{cs} \\
\mathrm{gs} \\
\mathrm{gs}\end{array}$ \\
\hline \multicolumn{7}{|c|}{ Bujeo Campiña (Typic Chromoxererts) } \\
\hline $\begin{array}{l}\text { Ap } \\
\text { A1 } \\
\text { C1ca } \\
\text { C2 } \\
\text { C3 }\end{array}$ & $\begin{array}{c}0-25 \\
25-35 \\
35-70 \\
70-120 \\
120-150\end{array}$ & $\begin{array}{l}2.5 Y 4 / 2 \\
2.5 Y 4 / 2 \\
2.5 Y 4 / 2 \\
2.5 Y 6 / 4 \\
2.5 Y 6 / 6\end{array}$ & $\begin{array}{l}c \\
c \\
c \\
c \\
c\end{array}$ & $\begin{array}{l}\text { f2sbk } \\
\text { m3abk } \\
\text { m3pr } \\
\text { m3pr } \\
\text { m }\end{array}$ & $\begin{array}{l}\mathrm{mfi} \\
\mathrm{mvfi} \\
\mathrm{mfi} \\
\mathrm{mfi} \\
\mathrm{mfi}\end{array}$ & $\begin{array}{l}\mathrm{gs} \\
\mathrm{gs} \\
\mathrm{gs} \\
\mathrm{d} \\
-\end{array}$ \\
\hline \multicolumn{7}{|c|}{ Albariza Estepa (Entic Haploxerolls) } \\
\hline $\begin{array}{l}\text { Apl } \\
\text { Ap2 } \\
\text { C }\end{array}$ & $\begin{array}{l}0-25 \\
25-35 \\
35-150\end{array}$ & $\begin{array}{l}10 \text { YR } 5 / 2 \\
10 \text { YR } 7 / 3 \\
7.5 \text { YR } 8 / 2\end{array}$ & $\begin{array}{l}\mathrm{c} \\
\mathrm{c} \\
\mathrm{cl}\end{array}$ & $\begin{array}{l}\mathrm{f} 2 \mathrm{cr} \\
\mathrm{f} 2 \mathrm{cr} \\
\mathrm{m}\end{array}$ & $\begin{array}{l}\mathrm{mfr} \\
\mathrm{mfr} \\
\mathrm{mfr}\end{array}$ & $\begin{array}{l}\mathrm{cs} \\
\mathrm{gs} \\
-\end{array}$ \\
\hline
\end{tabular}

† Symbols used are the same as given by Soil Survey Staff 1951, Agric. Handb. no. 18, p. 139-140).

serious disadvantage of the Albariza Estepa soil is the high $\mathrm{pH}$ in the $\mathrm{C}$ horizons due to the presence of carbonates $(>50 \%)$ which could cause $\mathrm{P}$ and minor element availability problems.

The maximum predicted yield for corn occurred on the Bujeo Campiña soil. However, irrigation can present serious problems in the Bujeo Campiña and Tierranegra Campo soils because the infiltration of water is low except in the cracks. Both soil types are among the most productive soils in Sevilla, where their somewhat poor natural drainage has been corrected by tile.

For cotton, the Tierranegra Campo soil has the best predicted yield, although a similar yield was calculated for the Bujeo Campiña soil. The presence of free carbonates in the materials of both soils could be a disadvantage in relation to $P$ and minor element 
Table 3-Chemical and physical characterization of the soil profiles.

\begin{tabular}{|c|c|c|c|c|c|c|c|c|c|c|c|c|c|c|c|c|c|}
\hline \multirow{3}{*}{$\begin{array}{l}\text { Hori- } \\
\text { zon }\end{array}$} & \multirow[b]{3}{*}{ Depth } & \multirow{2}{*}{\multicolumn{2}{|c|}{$\mathbf{p H}$}} & \multirow{2}{*}{\multicolumn{2}{|c|}{ Organic matter }} & \multirow{3}{*}{$\begin{array}{c}\mathbf{E C} \\
\times 10^{*} \\
\end{array}$} & \multirow{3}{*}{$\begin{array}{l}\mathrm{CaCO}, \\
\text { equiv. }\end{array}$} & \multirow[b]{3}{*}{ CEC } & \multirow{3}{*}{$\begin{array}{l}\text { Exch. } \\
\text { Na \% } \\
\text { (ESP) }\end{array}$} & \multirow{3}{*}{$\begin{array}{c}\text { Bulk } \\
\text { density }\end{array}$} & \multirow{3}{*}{$\begin{array}{l}\text { Hyd. } \\
\text { cond. }\end{array}$} & \multicolumn{2}{|c|}{ Water retention } & \multicolumn{4}{|c|}{ Particle size } \\
\hline & & & & & & & & & & & & \multirow{2}{*}{$\begin{array}{c}33 \\
\mathbf{k P a}\end{array}$} & \multirow{2}{*}{$\begin{array}{l}1500 \\
\mathrm{kPa}\end{array}$} & \multirow{2}{*}{$\begin{array}{c}\text { Coarse } \\
\text { sand }\end{array}$} & \multirow{2}{*}{$\begin{array}{l}\text { Fine } \\
\text { sand }\end{array}$} & \multirow[b]{2}{*}{ Silt } & \multirow[b]{2}{*}{ Clay } \\
\hline & & $\mathrm{H}_{2} \mathrm{O}$ & $\mathrm{KCl}$ & $\mathrm{C}$ & $\mathbf{N}$ & & & & & & & & & & & & \\
\hline & $\mathrm{cm}$ & & & - & $\longrightarrow$ & $\mathrm{d} S \mathrm{~m}^{-3}$ & $\%$ & $\mathrm{~mol} \mathrm{~kg}^{-1}$ & $\%$ & $\mathrm{~g} \mathrm{~cm}^{-3}$ & $\mathrm{~cm} \mathrm{~h}^{-1}$ & & & $-\%$ & & & \\
\hline \multicolumn{18}{|c|}{ Rojo Aljarafe (Typic Rhodoxeralfs) } \\
\hline $\begin{array}{l}\text { Ap } \\
\text { B1 } \\
\text { B2t } \\
\text { B3 } \\
\text { Cca }\end{array}$ & $\begin{array}{c}0-30 \\
30-55 \\
55-110 \\
110-120 \\
120-150\end{array}$ & $\begin{array}{l}7.5 \\
7.8 \\
7.8 \\
\text { nd } \dagger \\
\text { nd }\end{array}$ & $\begin{array}{l}6.5 \\
6.6 \\
6.4 \\
7.2 \\
7.0\end{array}$ & $\begin{array}{r}1.04 \\
0.42 \\
r 0.46 \\
0.42 \\
0.34\end{array}$ & $\begin{array}{l}0.10 \\
0.04 \\
0.05 \\
0.04 \\
0.04\end{array}$ & $\begin{array}{l}0.3 \\
1.0 \\
1.0 \\
\text { nd } \\
\text { nd }\end{array}$ & $\begin{array}{r}0.8 \\
0.8 \\
2.0 \\
48.0 \\
57.6\end{array}$ & $\begin{array}{l}0.16 \\
0.10 \\
0.19 \\
0.08 \\
0.08\end{array}$ & $\begin{array}{l}2.5 \\
2.0 \\
2.6 \\
\text { nd } \\
\text { nd }\end{array}$ & $\begin{array}{l}1.36 \\
1.35 \\
1.50 \\
1.41 \\
1.50\end{array}$ & $\begin{array}{l}2.6 \\
2.8 \\
1.6 \\
1.2 \\
2.1\end{array}$ & $\begin{array}{l}16.5 \\
14.1 \\
20.8 \\
18.9 \\
15.9\end{array}$ & $\begin{array}{r}11.2 \\
8.6 \\
12.1 \\
11.4 \\
4.2\end{array}$ & $\begin{array}{l}1.2 \\
0.8 \\
0.4 \\
8.7 \\
7.8\end{array}$ & $\begin{array}{l}64.7 \\
73.2 \\
59.7 \\
43.6 \\
44.6\end{array}$ & \begin{tabular}{r|}
7.4 \\
2.1 \\
3.8 \\
30.1 \\
28.6
\end{tabular} & $\begin{array}{l}25.8 \\
22.5 \\
35.5 \\
16.8 \\
17.7\end{array}$ \\
\hline \multicolumn{18}{|c|}{ Tierranegra Campo (Typic Pelloxererts) } \\
\hline $\begin{array}{l}\text { Ap } \\
\text { A1 } \\
\text { AC } \\
C\end{array}$ & $\begin{array}{c}0-20 \\
20-60 \\
60-140 \\
140-170\end{array}$ & $\begin{array}{l}7.7 \\
7.8 \\
8.5 \\
8.4\end{array}$ & $\begin{array}{l}6.8 \\
6.8 \\
7.2 \\
7.1\end{array}$ & $\begin{array}{l}0.80 \\
0.65 \\
0.46 \\
0.50\end{array}$ & $\begin{array}{l}0.09 \\
0.07 \\
0.06 \\
0.05\end{array}$ & $\begin{array}{l}1.1 \\
1.6 \\
1.3 \\
1.3\end{array}$ & $\begin{array}{l}12.8 \\
14.8 \\
22.4 \\
22.4\end{array}$ & $\begin{array}{l}0.40 \\
0.35 \\
0.45 \\
0.42\end{array}$ & $\begin{array}{l}0.5 \\
1.0 \\
1.0 \\
1.7\end{array}$ & $\begin{array}{l}1.43 \\
1.53 \\
1.53 \\
1.48\end{array}$ & $\begin{array}{l}1.7 \\
1.0 \\
0.1 \\
0.1\end{array}$ & $\begin{array}{l}42.1 \\
36.8 \\
38.0 \\
37.1\end{array}$ & $\begin{array}{l}23.5 \\
20.1 \\
20.8 \\
19.7\end{array}$ & $\begin{array}{r}8.7 \\
9.1 \\
8.2 \\
12.0\end{array}$ & $\begin{array}{l}21.8 \\
22.1 \\
12.4 \\
20.0\end{array}$ & $\begin{array}{l}24.1 \\
29.2 \\
26.1 \\
16.5\end{array}$ & $\begin{array}{l}45.8 \\
39.1 \\
52.2 \\
50.0\end{array}$ \\
\hline \multicolumn{18}{|c|}{ Salino Marismas (Vertic Fluvaquents) } \\
\hline $\begin{array}{l}\text { Alsa } \\
\text { C1 sa } \\
\text { C2sa }\end{array}$ & $\begin{array}{l}0-10 \\
10-20 \\
20-100\end{array}$ & $\begin{array}{l}7.5 \\
8.0 \\
8.0\end{array}$ & $\begin{array}{l}\text { nd } \\
\text { nd } \\
\text { nd }\end{array}$ & $\begin{array}{l}1.44 \\
1.10 \\
0.56\end{array}$ & $\begin{array}{l}0.15 \\
0.09 \\
0.06\end{array}$ & $\begin{array}{l}53.4 \\
45.4 \\
50.6\end{array}$ & $\begin{array}{l}22.8 \\
22.7 \\
22.5\end{array}$ & $\begin{array}{l}0.28 \\
0.30 \\
0.28\end{array}$ & $\begin{array}{l}22.0 \\
22.5 \\
30.0\end{array}$ & $\begin{array}{l}1.43 \\
1.44 \\
1.42\end{array}$ & $\begin{array}{l}0.1 \\
- \\
-\end{array}$ & $\begin{array}{l}33.5 \\
37.2 \\
35.1\end{array}$ & $\begin{array}{l}26.7 \\
28.5 \\
27.3\end{array}$ & $\begin{array}{l}0.3 \\
0.1 \\
0.3\end{array}$ & $\begin{array}{l}1.8 \\
2.0 \\
5.3\end{array}$ & $\begin{array}{l}34.5 \\
27.0 \\
35.0\end{array}$ & $\begin{array}{l}63.5 \\
71.0 \\
59.0\end{array}$ \\
\hline \multicolumn{18}{|c|}{ Franco Vega (Typic Xerofluvents) } \\
\hline $\begin{array}{l}\text { Ap } \\
\mathrm{C1} \\
\mathrm{C2} \\
\mathrm{C} 3\end{array}$ & $\begin{array}{c}0-25 \\
25-55 \\
55-80 \\
80-150\end{array}$ & $\begin{array}{l}7.7 \\
7.8 \\
8.0 \\
8.1\end{array}$ & $\begin{array}{l}6.9 \\
6.9 \\
7.0 \\
7.0\end{array}$ & $\begin{array}{l}0.95 \\
0.76 \\
0.70 \\
0.47\end{array}$ & $\begin{array}{l}0.09 \\
0.07 \\
0.07 \\
0.05\end{array}$ & $\begin{array}{l}1.9 \\
2.1 \\
1.6 \\
2.5\end{array}$ & $\begin{array}{l}24.5 \\
25.2 \\
27.0 \\
29.1\end{array}$ & $\begin{array}{l}0.11 \\
0.11 \\
0.10 \\
0.07\end{array}$ & $\begin{array}{l}5.0 \\
5.0 \\
3.3 \\
4.1\end{array}$ & $\begin{array}{l}1.41 \\
1.49 \\
1.38 \\
1.36\end{array}$ & $\begin{array}{l}1.0 \\
0.7 \\
1.2 \\
1.2\end{array}$ & $\begin{array}{l}22.4 \\
22.7 \\
20.4 \\
13.2\end{array}$ & $\begin{array}{l}9.1 \\
9.1 \\
7.5 \\
5.3\end{array}$ & $\begin{array}{l}0.9 \\
1.0 \\
0.5 \\
0.7\end{array}$ & $\begin{array}{l}46.5 \\
45.5 \\
57.8 \\
75.8\end{array}$ & $\begin{array}{r}20.5 \\
26.3 \\
18.2 \\
3.3\end{array}$ & $\begin{array}{l}28.5 \\
24.2 \\
20.5 \\
17.3\end{array}$ \\
\hline \multicolumn{18}{|c|}{ Arena Terrazas (Aquic Haploxeralfe) } \\
\hline $\begin{array}{l}\text { Ap } \\
\text { B1 } \\
\text { B21tg } \\
\text { B22tg } \\
\text { B3tg }\end{array}$ & $\begin{array}{c}0-25 \\
25-40 \\
40-70 \\
70-110 \\
110-150\end{array}$ & $\begin{array}{l}6.7 \\
6.9 \\
7.8 \\
7.8 \\
8.1\end{array}$ & $\begin{array}{l}5.5 \\
5.8 \\
6.6 \\
6.6 \\
6.9\end{array}$ & $\begin{array}{l}0.14 \\
0.11 \\
0.23 \\
0.16 \\
0.11\end{array}$ & $\begin{array}{c}0.02 \\
0.01 \\
0.02 \\
0.02 \\
. .\end{array}$ & $\begin{array}{l}3.2 \\
5.2 \\
4.4 \\
\text { nd } \\
\text { nd }\end{array}$ & $\begin{array}{l}= \\
= \\
8.2\end{array}$ & $\begin{array}{l}0.05 \\
0.10 \\
0.23 \\
0.26 \\
0.24\end{array}$ & $\begin{array}{l}7.0 \\
4.0 \\
4.1 \\
7.0 \\
6.1\end{array}$ & $\begin{array}{l}1.61 \\
1.70 \\
1.79 \\
1.63 \\
1.75\end{array}$ & $\begin{array}{l}2.1 \\
0.3 \\
0.1 \\
- \\
-\end{array}$ & $\begin{array}{l}12.7 \\
17.2 \\
10.0 \\
12.0 \\
12.5\end{array}$ & $\begin{array}{l}6.8 \\
9.2 \\
5.4 \\
7.1 \\
6.9\end{array}$ & $\begin{array}{l}34.2 \\
33.1 \\
20.4 \\
17.3 \\
19.5\end{array}$ & $\begin{array}{l}44.4 \\
30.4 \\
25.4 \\
24.0 \\
20.0\end{array}$ & $\begin{array}{r}6.4 \\
8.9 \\
9.2 \\
10.5 \\
12.1\end{array}$ & $\begin{array}{l}14.7 \\
25.5 \\
42.6 \\
45.2 \\
45.4\end{array}$ \\
\hline \multicolumn{18}{|c|}{ Almagra Alcores (Calcic Haploxeralfs) } \\
\hline $\begin{array}{l}\text { Ap } \\
\text { AB } \\
\text { B2t } \\
\text { B3ca } \\
\text { C1ca } \\
\text { IIC2ca }\end{array}$ & $\begin{array}{c}0-20 \\
20-45 \\
45-60 \\
60-75 \\
75-115 \\
115-200\end{array}$ & $\begin{array}{l}7.8 \\
8.0 \\
7.9 \\
8.0 \\
8.0 \\
8.1\end{array}$ & $\begin{array}{l}6.7 \\
6.6 \\
6.6 \\
6.8 \\
6.8 \\
7.0\end{array}$ & $\begin{array}{l}1.19 \\
0.81 \\
0.50 \\
0.54 \\
0.68 \\
0.40\end{array}$ & $\begin{array}{l}0.10 \\
0.08 \\
0.05 \\
0.05 \\
0.07 \\
0.04\end{array}$ & $\begin{array}{l}0.2 \\
0.3 \\
1.2 \\
1.5 \\
0.5 \\
\text { nd }\end{array}$ & $\begin{array}{c}- \\
- \\
28.8 \\
50.0 \\
50.1\end{array}$ & $\begin{array}{c}0.07 \\
0.08 \\
0.13 \\
0.07 \\
\text { nd } \\
\text { nd }\end{array}$ & $\begin{array}{l}4.0 \\
3.7 \\
2.0 \\
3.8 \\
\text { nd } \\
\text { nd }\end{array}$ & $\begin{array}{l}1.59 \\
1.43 \\
1.53 \\
1.71 \\
1.78 \\
1.78\end{array}$ & $\begin{array}{l}1.1 \\
3.3 \\
0.7 \\
\text { nd } \\
0.3 \\
0.2\end{array}$ & $\begin{array}{l}18.4 \\
22.3 \\
26.4 \\
20.4 \\
18.8 \\
15.9\end{array}$ & $\begin{array}{r}11.3 \\
15.7 \\
18.3 \\
11.2 \\
9.2 \\
6.3\end{array}$ & $\begin{array}{r}9.9 \\
6.9 \\
4.7 \\
6.1 \\
6.9 \\
19.3\end{array}$ & $\begin{array}{l}47.7 \\
48.7 \\
45.1 \\
36.2 \\
27.9 \\
32.0\end{array}$ & $\begin{array}{r}7.4 \\
3.1 \\
5.0 \\
24.4 \\
34.9 \\
27.2\end{array}$ & $\begin{array}{l}31.3 \\
39.7 \\
43.2 \\
28.5 \\
25.2 \\
17.3\end{array}$ \\
\hline \multicolumn{18}{|c|}{ Bujeo Campiña (Typic Chromoxererts) } \\
\hline $\begin{array}{l}\text { Ap } \\
\text { A1 } \\
\text { C1ca } \\
\text { C2 }\end{array}$ & $\begin{array}{c}0-25 \\
25-35 \\
35-70 \\
70-120\end{array}$ & $\begin{array}{l}7.5 \\
7.6 \\
7.9 \\
7.7\end{array}$ & $\begin{array}{l}6.8 \\
6.7 \\
6.8 \\
7.0\end{array}$ & $\begin{array}{l}0.74 \\
0.63 \\
0.42 \\
0.17\end{array}$ & $\begin{array}{l}0.09 \\
0.08 \\
0.06 \\
0.02\end{array}$ & $\begin{array}{l}0.7 \\
1.1 \\
3.2 \\
5.5\end{array}$ & $\begin{array}{l}31.0 \\
31.4 \\
34.2 \\
32.8\end{array}$ & $\begin{array}{l}0.39 \\
0.38 \\
0.38 \\
0.37\end{array}$ & $\begin{array}{r}0.4 \\
0.7 \\
8.4 \\
14.0\end{array}$ & $\begin{array}{l}1.64 \\
1.63 \\
1.71 \\
1.69\end{array}$ & $\begin{array}{l}0.4 \\
0.2 \\
- \\
0.2\end{array}$ & $\begin{array}{l}30.5 \\
28.7 \\
29.5 \\
27.4\end{array}$ & $\begin{array}{l}21.6 \\
19.9 \\
19.9 \\
18.6\end{array}$ & $\begin{array}{l}4.6 \\
2.8 \\
2.8 \\
2.2\end{array}$ & $\begin{array}{l}25.1 \\
26.4 \\
26.3 \\
32.5\end{array}$ & $\begin{array}{l}17.4 \\
19.5 \\
19.7 \\
23.5\end{array}$ & $\begin{array}{l}52.5 \\
48.7 \\
50.6 \\
39.6\end{array}$ \\
\hline \multicolumn{18}{|c|}{ Albariza Estepa (Entic Haploxerolls) } \\
\hline $\begin{array}{l}\text { Ap1 } \\
\text { Ap2 } \\
\text { C } \\
\end{array}$ & $\begin{array}{c}0-25 \\
25-35 \\
35-150\end{array}$ & $\begin{array}{l}8.2 \\
8.2 \\
8.3 \\
\end{array}$ & $\begin{array}{l}7.0 \\
7.3 \\
7.3 \\
\end{array}$ & $\begin{array}{l}0.91 \\
0.91 \\
0.16 \\
\end{array}$ & $\begin{array}{l}0.09 \\
0.09 \\
0.02 \\
\end{array}$ & $\begin{array}{l}0.2 \\
0.3 \\
\text { nd }\end{array}$ & $\begin{array}{l}48.0 \\
48.5 \\
52.2 \\
\end{array}$ & $\begin{array}{c}0.25 \\
0.26 \\
\text { nd } \\
\end{array}$ & $\begin{array}{l}0.5 \\
0.5 \\
\text { nd } \\
\end{array}$ & $\begin{array}{l}1.28 \\
1.28 \\
1.34 \\
\end{array}$ & $\begin{array}{l}6.5 \\
5.9 \\
3.5 \\
\end{array}$ & $\begin{array}{l}26.4 \\
26.1 \\
25.2 \\
\end{array}$ & $\begin{array}{l}14.7 \\
14.5 \\
15.3 \\
\end{array}$ & $\begin{array}{l}12.7 \\
13.1 \\
20.7 \\
\end{array}$ & $\begin{array}{r}17.7 \\
10.5 \\
9.5 \\
\end{array}$ & $\begin{array}{l}25.6 \\
34.7 \\
30.4 \\
\end{array}$ & $\begin{array}{l}41.0 \\
41.2 \\
36.3 \\
\end{array}$ \\
\hline
\end{tabular}

† nd - not determined.

availability. The Rojo Aljarafe and Almagra Alcores soils have a moderate suitability for cotton, as well as for wheat and corn. The difference between cotton yield in both soil types is insignificant. They have somewhat unfavorable physical properties due to a high clay content in the B2 horizons.

Predicted yields for Salino Marismas soil were calculated assuming potential soil conditions following reclamation. The potential soil conditions include an upper layer of $50 \mathrm{~cm}$ where the salt content and sodium saturation have been considerably reduced (EC $=7 \mathrm{dS} \mathrm{m}^{-1}$ and ESP $=8 \%$, maximum values in the calibration of De la Rosa et al. (11) models), and where the improved physical properties allowed good alteration and moderate permeability. However, the Salino Marismas soil, as characterized in Tables 2 and 3, has unfavorable physical and chemical properties that limit any crop growth.
Table 4-Estimated agricultural potential of the selected benchmark soils by application of De la Rosa et al. system. $\dagger$

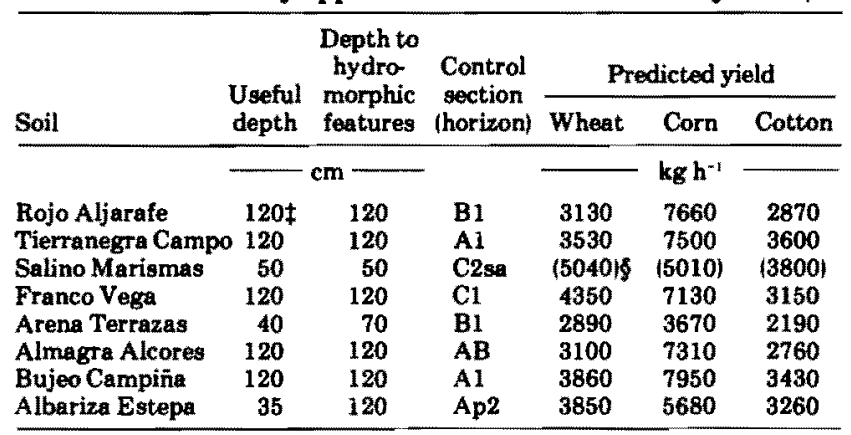

t For system polynomial models and definition of variables see De la Rosa et al. (1981).

$\ddagger 120 \mathrm{~cm}$ is the maximum useful depth considered in the soil evaluation system.

$\$$ Parentheses denote potential yield values in the case that this soil was reclaimed. 


\section{ACKNOWLEDGMENTS}

The authors gratefully acknowledge with thanks Dr. V.W. Carlisle, Dep. of Soil Sci., Univ. of Florida, for helpful criticism and review of this paper.

\section{REFERENCES}

1. Allison, L.E. 1965. Organic carbon. In C.A. Black et al. (ed.) Methods of soil analysis, part 2. Agronomy 9:136-1378. Am. Soc. of Agron., Madison, Wis.

2. Bartelli, L.J. 1979. Interpreting soil data. In M.T. Beatty et al. (ed.) Planning the uses and management of land. Agronomy 21:91-116. Agron., Madison, Wis.

3. Beck, K.J. 1980. From soil survey interpretation to land evaluation. ILRI Reprint no. 15, Wageningen, The Netherlands.

4. Bennema, J. 1978. Land evaluation for agricultural land use planning. L.D. Swindale (ed.) Soil-resource data for agricultural development. Hawaii Agric. Exp. Stn. Res. Rep. Honolulu, Hawaii.

5. Bouyoucos, G.J. 1962. Hydrometer method improved for making particle size analyses of soils. Agron. J. 54:464-465.

6. Cardoso, J.V. 1965. Os solos de Portugal. Sua classificaçao, caracteriçao e genese. Pub. Secret. Est. Agric. Lisboa, Portugal.

7. Centro de Edafología y Biología Aplicada del Cuarto. 1962. Estudio agrobiológico de la Provincia de Sevilla. Pub. CEBAC, Sevilla, Spain.

8. Chapman, H.D. 1965. Cation exchange capacity. In C.A. Black et al. (ed.) Methods of soil analysis, Part 2. Agronomy 9:891904. Am. Soc. of Agron., Madison, Wis.

9. Cline, M.G. 1977. Historical highlights in soil genesis, morphology and classification. Soil Sci. Soc. Am. J. 41:250-254.
10. De la Rosa, D. 1975. Reconocimiento y evaluación de suelor de terrazas del Guadalquivir en la Provincia de Sevilla. Ph.D. Thesis. Madrid Univ, Spain.

11. De la Rosa, D., F. Cardona, and J. Almorza. 1981. Crop yidld predictions based on properties of soils in Sevilla, Spain. Ceoderma 25:267-274.

12. González-Garcia, F.. and J.L. Pérez-Rodríguez. 1970. Constitución y propiedades fisicoquímicas de las arcillas de suelos del Valle del Guadalquivir. II. Suelos rojos mediterráneos. An. Edafol. Agrobiol, 29:821-830.

13. Miller, F.T., and J.D. Nichols. 1979. Soils data. In M.T. Beatty et al. (ed.) Planning the uses and management of land. Agronomy 21:67-90. Am. Soc. of Agron., Madison, Wis.

14. Moreno, F., J. Arrúe, J.M. Murillo, J.L. Pêrez, and J. MartinAranda. 1980. Mineralogical composition of clay fraction in marsh soils of SW Spain. Pol. J. Soil Sci. 13:65-72.

15. Mudarra, J.L. 1974. Estudio de los suelos de la Cuenca del Guadalquivir. Ph.D. Thesis. Sevilla Univ., Spain.

16. Paneque, G., and J.L. Mudarra. 1966. Morfología, sistemática y cartografia de los suelos de Andalucía Occidental. p. 417-427 Medit. Soils Conf. Proc., Madrid, Spain.

17. Slabbers, P.J., V. Sorbello, and M. Stapper. 1979. Evaluation of simplified water-crop yield models. Agric. Water Mgt. 2 :95130.

18. Soil Survey Staff. 1951. Soil survey manual. Agric. Handb. no. 18 , USDA. U.S. Government Printing Office, Washington, DC.

19. Soil Survey Staff. 1972. Soil survey laboratory methods and procedures for collecting soil samples. Soil Invest. Rep. no. 1, USDA. U.S. Government Printing Office, Washington, DC.

20. Soil Survey Staff. 1975. Soil taxonomy. A basic system of soil classification for making and interpreting soil surveys. Agric. Handb. no. 436, USDA. U.S. Government Printing Office, Washington, DC. 